Original Research Paper

\title{
Impact of Absorbing Agent on Moisture Reserves of Winter Wheat in the Conditions of Semiprovided Dry Farming Land of the South-East of Kazakhstan
}

\author{
${ }^{1}$ Laila Klimovna Tabynbayeva, ${ }^{2}$ Serik Barmenbekovich Kenenbayev, \\ ${ }^{2}$ Meiramgul Shagievna Suleimenova, ${ }^{2}$ Nurlan Kairbekovich Tinibayev and ${ }^{3}$ Vasiliy Sergeevich Boiko \\ ${ }^{I}$ Noncommercial Corporation Kazakh National Agrarian University, \\ Kazakhstan, 050010, Almaty, Abay Avenue 8, Kazakhstan \\ ${ }^{2}$ LLPKazakh Research Institute of Agriculture and Crop Production, Kazakhstan, 040909, Kazakhstan \\ Almaty Oblast, Karasay Region, Village Almalybak, Erlepesov Street 1, Kazakhstan \\ ${ }^{3}$ FSSI "Siberian Scientific Research Institute of Agriculture" Russia, 644012, Omsk, 26 Koroleva Avenue, Russia
}

Article history

Received: 24-02-2017

Revised: 17-05-2017

Accepted: 27-05-2017

Corresponding Author: Laila Klimovna Tabynbayeva Noncommercial Corporation Kazakh National Agrarian

University, Kazakhstan, 050010, Almaty, Abay

Avenue 8, Kazakhstan

Email: tabynbaeva.lyaylya@mail.ru

\begin{abstract}
In the conditions of dry-land farming, the leading factor of productivity, which is minimal, is moisture. Soil moisture directly influences the growth of plants by means of aeration, transfer of nutrient substances, absorption and transformation. The main crop acreage of the spike cereals in the south-east of Kazakhstan is located in dry farming lands that are characterized as dry and semidry, which means the region has a water deficit. The lack of natural moisture reserves, especially in dry years, as a rule, is one of the main reasons for the reduction in yields of winter wheat, which is the leading crop of non irrigated farming. The objective of this research is to determine the impact of the absorbing agent" Aquasorb" on the moisture reserve of soil and the yield of winter wheat. The research was performed in the field stationary land lot of the Kazakh Research Institute of Agriculture and Crop Production in the conditions of the semi provided dry farming land in the south-east of Kazakhstan. The field test was performed by means of applying the famous water-retaining absorbing agent "Aquasorb" before seeding winter wheat. The following application rates of the absorbing agent were used in the test: $0,20,40 \mathrm{~kg} / \mathrm{ha}$ and their combination with the nitrogen top dressing in the dose $\mathrm{N}_{45}$. The results of the research revealed that the absorbing agent applied in the soil improved significantly the provision of winter wheat plants with the available moisture during the vegetation period and also made it possible to efficiently use the moisture for the formation of high yield.
\end{abstract}

Keywords: Winter Wheat, Absorbing Agent, Moisture Provision, Yield

\section{Introduction}

Due to the climate, Kazakhstan is a zone of risky farming, especially the south and the south-east regions. In this regard, the main task of dry-land farming in Kazakhstan is to increase the moisture reserves of crops by means of looking for the methods of the efficient use of the natural moisture (precipitation in the form of rain, melt waters, etc.) and to develop the practical measures of drought control. The main crop acreage of the spiked cereals in the south-east of Kazakhstan is located in the dry farming lands characterized as dry and semidry.

In the period of the active growth and development of winter wheat, the fast augmentation of the soil drought from spring to summer takes place in this area, when the acute deficiency of moisture is observed in the soil and also in the air, especially in the period of formation and filling of grain, which preconditions decreasing water reserves and leads to a reduction in yields (Nurbekov, 2010).

In recent years, due to the global warming and with a purpose of improving the moisture reserves of soils and plants and increasing their productivity in the dry regions of the world, scientists recommend to use hydrogel (Johnson, 1984; Bowman and Evans, 1991). The authors mentioned that hydrogels are super absorbing agents that absorb and hold hundred times more water than their own weight, that is, $400-1500 \mathrm{~g}$ of water per $1 \mathrm{~g}$ of dry hydrogel. The hydrogel capacity is determined according 
to its chemical properties and the chemical content of the soil solution or irrigating waters.

In many studies, scientists studying the polymeric materials distinguish the agricultural polymers that were developed to improve the physical properties of soil taking into account: The increase in their moistureretaining capacity; the increase in the efficiency of water use; the increase in the soil permeability; the decrease in the irrigation rate; the decrease in the consolidation tendency; preventing erosion and aqueous runoff; the increase in the plant capacity (especially in the structure less soil in the regions subjected to drought).

The polymers used in the agriculture have two different types:

- Water-soluble polymers are the linear soluble hydrophylic or ionic polymers, used as wetting agents

- Gel forming polymers are cross-linked chains that form the three-dimension network

Most polymers are cross-linked polyacrilamides from the copolymers of acrilamides with acryl ate that as it is proved stay active for a longer period of time. These products are synthetic substances and are promoted to be used as additional agents for production of plants in the arid conditions where water resources are a limiting factor (Jhurry, 1997; Ekebafe et al., 2011; Barihi et al., 2013; Puoci et al., 2008).

The numerous studies showed their efficiency in the improvement of the soil structure, the increase in the water permeability and water saving and also in the decrease in the infiltration degree (Helalia and Letey, 1989; Choudhary et al., 1995; Al-Darby, 1996; Hüttermann et al., 2009).

Orikiriza et al. (2009) supposed that the application of hydrogel increases the efficiency of the permeability and use of moisture by the plants grown on the soils having their content close to the field capacity. The use of the super absorbing polymer removes significantly the consequences of the drought and that helps the active development of the plants and the formation of the yield sustainability (Khadem et al., 2010). The use of hydrogels led to the significant decrease in the number of irrigations, especially for the soils with large-scale texture (Abedi-Koupai and Sohrab, 2004)

In the research of (Sabrah et al. 1993; Saifuldeen, 2014), with the increase of the hydrogel dose, the soil mass decreased, which resulted positively in the increasing porosity and the formation of stable soil aggregates in comparison with the control background.

The Russian scientist (Krotov, 1996) studying the impact of the hydrogel on the dynamics of soil moisture revealed that when applying the hydrogel the positive effect was observed in the increase in the soil moisture and also in the increase in the productive soil moisture, especially when the dose is increasing.

Among the well-known super hydrogels, the synthetic polymer Aquasorb has become famous among the agricultural manufacturers.

The research of the application of the absorbing agent Aquasorb in Kazakhstan was not conducted. Therefore, the use of the hydrophilic polymers can be considered as a new technical solution to increase the moisture reserves of the leading field crops in the south-east of the country. When solving the problem of the increase in crop yields at the level of the whole agrobiocenoses, the problems always arise caused by the rotation of drought years and years with a lot of precipitation that influence significantly the efficiency of their use. Alongside with that, in the natural ecological environments, the deviations of the weather factors from the long-term average annual values can be observed that take place in the studied region of Kazakhstan, which influences negatively the production process of crops.

\section{Materials and Methods of Research}

The research was performed in the field stationary land lot of the Kazakh Research Institute of Agriculture and Crop Production (KazRIACP) in 2015-2016. The region is characterized by the relatively mild winter, the cool humid spring, the hot summer and the warm and dry autumn. The weather conditions for the years of research differed much; the total amount of precipitation for the vegetation period (spring-summer) in 2015 was $305.0 \mathrm{~mm}$ and in 2016 it was $610.9 \mathrm{~mm}$. The deviation from the long-term average annual data is $+73.4 \mathrm{~mm}$ and $+379.3 \mathrm{~mm}$ accordingly. The analysis of the meteorological conditions for the years of research (2015-2016) was performed according to the data of the hydrometeo station of Kaz RIACP.

The soil of the field test is light-brown soil containing up to $2 \%$ of humus. The variety of winter wheat is Glazed 24; the seeding rate is $4.5 \mathrm{mln}$ viable seeds/hectare. The agricultural technology applied is general: Subsurface cultivator processing at a depth of 20-22 cm using the cultivatorKPG-2-150, pre-seeding treatment with soil spikers (BIG-3A). The seeding of winter wheat was performed by the direct seed drill" Agro master" seeding depth is 3-4 cm.

The field test was performed in two backgrounds: Control (without absorbing agent) and without nitrogen top dressing in the dose $\mathrm{N}_{45}$ and two application rates of the absorbing agent Aquasorb-20 and $40 \mathrm{~kg} / \mathrm{ha}$ and their combination with nitrogen top dressing. The variants were repeated 3 times and applied systematically. The research was performed according to Dospekhov's method (Dospekhov, 1985). 


\section{Results}

The results of the research conducted in 2015-2016 showed that the application of the absorbing agent Aquasorb under the seeding is an efficient method of improving the moisture reserves of the crops of winter wheat, especially when applying it without irrigation. It was revealed that the reserves of the productive moisture in the meter layer when applying the absorbing agent at the rates of 20 and $40 \mathrm{~kg} / \mathrm{ha}$ in the period of the spring tillering of winter wheat for the variant without top dressing fluctuated in the range of $13-19 \mathrm{~mm}$ or 10.3 $19.0 \%$ higher in comparison with the control background (without absorbing agent) and when applying the nitrogen top dressing in the dose $\mathrm{N}_{45}$ in the range of 30$39 \mathrm{~mm}$ or $23.9-31.0 \%$, accordingly. The biggest reserves of the productive moisture in the crops of winter wheat were observed when applying the absorbing agent at the rate of $40 \mathrm{~kg} / \mathrm{ha}$. The lowest values were observed in the variant with $\mathrm{N}_{45}$; it was $6 \mathrm{~mm}(4.8 \%)$ higher that the control background. In the earing phase, the exceed of the reserves of the productive moisture depending upon the application of the absorbing agent in comparison with the control background was $23-27 \mathrm{~mm}$ or $18.7-22.0 \%$ for the variants without top dressing and with top dressing it was $29-38 \mathrm{~mm}$ or $23.6-30.9 \%$, accordingly. The growth of the productive moisture reserves in case of the application of nitrogen top dressing without absorbing agent amounted to $22 \mathrm{~mm}$ or $17.9 \%$ in comparison with the control background.

During the yielding period, the difference of the content of productive moisture in the meter layer between the variants with the absorbing agent and control background without topdressing was equal to 14$18 \mathrm{~mm}$ or $22.2-28.6 \%$ and with it-25-30 $\mathrm{mm}$ or 39.7 $47.6 \%$, accordingly (Fig. 1).

During the vegetation period, due to the absorbing agent, winter wheat received much more moisture from the soil. The application of the absorbing agent at the rate of 20 and $40 \mathrm{~kg} / \mathrm{ha}$ led to a small increase in the total water consumption by 25 and $5 \mathrm{~m}^{3} /$ ha in comparison with the control where the absorbing agent and the top dressing were not applied. For the crops with the joint application of the nitrogen top dressing and the absorbing agent at the application rates of 20 and 40 $\mathrm{kg} / \mathrm{ha}$, the increase in the total water consumption was 120 and $155 \mathrm{~m}^{3} /$ ha, accordingly (Table 2 ).

For the crops of winter wheat, the most economic moisture consumption was observed on the background with the joint application of the nitrogen topdressing and absorbing agent at the rate of $40 \mathrm{~kg} / \mathrm{ha}$. The coefficient of the water consumption was $145.1 \mathrm{~m}^{3} / \mathrm{c}$, which in comparison with the control background is less by 40.9 $\mathrm{m}^{3} / \mathrm{c}$. A little higher moisture consumption of winter wheat was observed in the variant with Aquasorb 20 $\mathrm{kg} / \mathrm{ha}+\mathrm{N}_{45^{-}}-158.5 \mathrm{~m}^{3} / \mathrm{c}$. The maximal moisture consumption for the formation of the crop yield was obtained on the control background $-186.0 \mathrm{~m}^{3} / \mathrm{c}$.

\section{Discussion}

Analyzing the data specified in Fig. 1, it is evident that the reserves of the productive moisture were used most intensively in the production process at the combined action of the absorbing agent at the application rate of $40 \mathrm{~kg} / \mathrm{ha}$ with the nitrogen topdressings in the dose $\mathrm{N}_{45}$. The similar dependence was revealed for all the studied phases of growth and development of the plants.

Thus, according to the results of the research, it was revealed that the absorbing agent Aquasorb is efficient for increasing the productive moisture in the meter layer of winter wheat, especially in combination with the nitrogen top dressing in the dose $\mathrm{N}_{45}$. According to the results of the two-year research, the high response of the soil and plants was revealed to the application of the absorbing agent under the crop at the rate of $40 \mathrm{~kg} / \mathrm{ha}$.

The yield of winter wheat as any other crop is a final result of the experiment. During the years of the research of winter wheat crops, the impacts of various forms of the absorbing agent, topdressing of the nitrogen fertilizers in the dose $\mathrm{N}_{45}$ on the moisture reserves and the yield of this crop were studied.

The analysis of the literature shows that the application of the resource-saving technology in the agriculture is the main direction and the application of the resource-saving technologies not only makes it possible to increase the yield significantly but helps to solve several problems at the same time using the same investments: Increasing the soil fertility, fighting soil erosion, the modernization of the branch and increasing the economic efficiency of the production.

As we can see from Table 1, the growth of yield of winter wheat from the joint application of the absorbing agent and the top dressing is significant only at the rate of $40 \mathrm{~kg} / \mathrm{ha}$ and when applying $20 \mathrm{~kg} / \mathrm{ha}$ at one level between the backgrounds without top dressing and with top dressing. This points to the efficient action of the agent on the level of the soil moisture at the application rate of $40 \mathrm{~kg} / \mathrm{ha}$ (4.9 and $6.6 \mathrm{c} / \mathrm{ha})$ against the rate of $20 \mathrm{~kg} / \mathrm{ha}$.

In the dry farming, the total water consumption plays an important role that consists of the values such as the reserves of the productive moisture (spring and yield moisture) and the sum of the precipitations for the vegetation period. The productivity of the moisture use is usually expressed by its consumption to the creation of the dry basis unit-water consumption coefficient. This coefficient is specific for every crop and is changing depending upon the vegetation period level of soil fertility, doses of the fertilizers and other factors. The lower the level of the agricultural technology and the soil fertility is, the higher the water consumption coefficient is. 


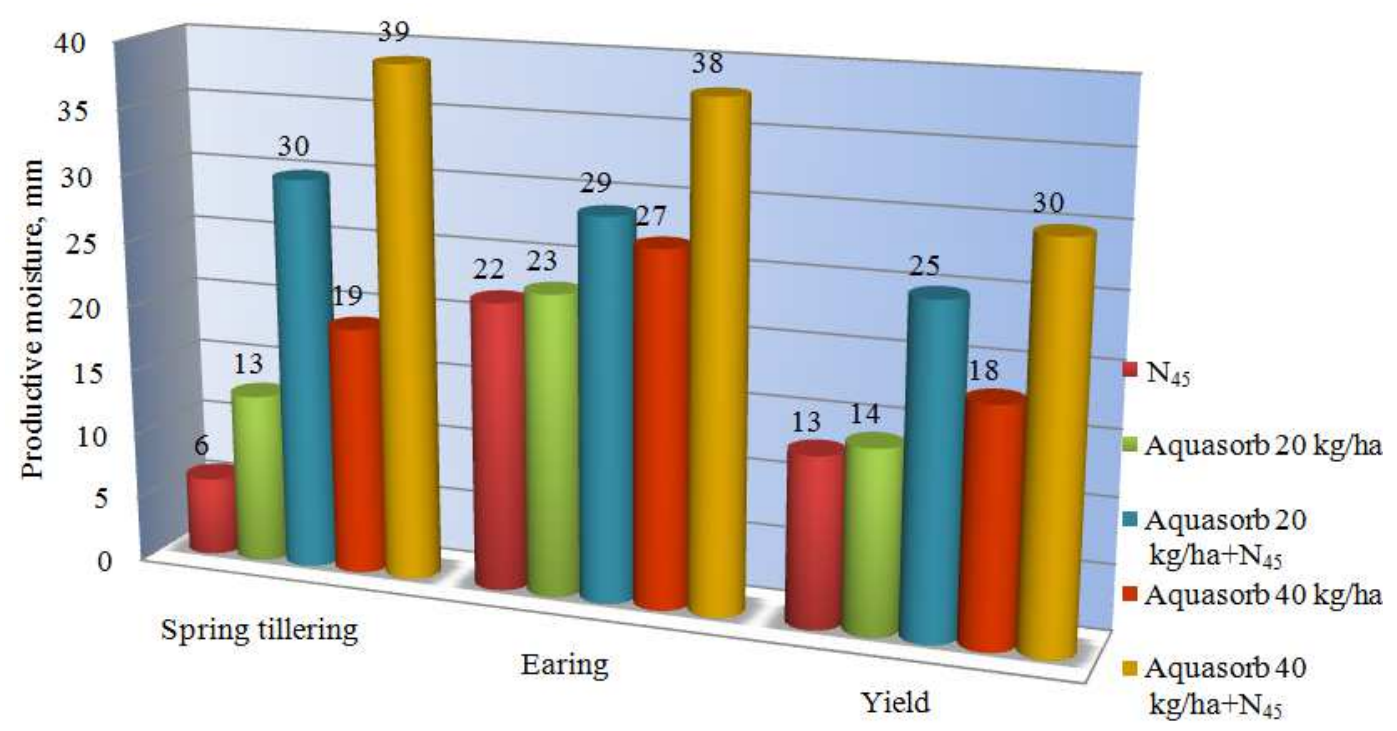

Fig. 1. Growth of the productive moisture reserves depending upon the application of the absorbing agent and nitrogen top dressing (on the average for 2015-2016)

Table 1. Impact of the application rate of the absorbingagent Aquasorb and the nitrogen top dressing on the winter wheat yield, c/ha (on the average for 2015-2016)

\begin{tabular}{|c|c|c|c|c|c|}
\hline \multirow[b]{2}{*}{ Background (A) } & \multicolumn{3}{|c|}{ Application rates of the absorbing agent, $\mathrm{kg} / \mathrm{ha}(\mathrm{B})$} & \multicolumn{2}{|c|}{ Yield growth, c/ha } \\
\hline & 0 & 20 & 40 & 20 & 40 \\
\hline Without top dressing & 28.0 & 30.3 & 32.9 & 2.3 & 4.9 \\
\hline With topdressing & 29.9 & 32.2 & 36.5 & 2.3 & 6.6 \\
\hline \multicolumn{6}{|l|}{ HCP $95 \%=2.508$} \\
\hline HCP 95\%: According & -1.44 & le fact & & & \\
\hline
\end{tabular}

Table 2. Impact of the absorbing agent on the water consumption coefficient of winter wheat (on the average for 2015-2016)

\begin{tabular}{|c|c|c|c|c|c|c|}
\hline & \multicolumn{2}{|c|}{$\begin{array}{l}\text { Reserves of productive } \\
\text { moisture }(\mathrm{mm})\end{array}$} & \multirow{2}{*}{$\begin{array}{l}\text { Precipitation } \\
\text { during } \\
\text { vegetation, } \mathrm{mm}\end{array}$} & \multirow{2}{*}{$\begin{array}{l}\text { Total water } \\
\text { consumption, } \\
\mathrm{m}^{3} / \text { ha }\end{array}$} & \multirow{2}{*}{$\begin{array}{l}\text { Yield, } \\
\text { c/ha }\end{array}$} & \multirow{2}{*}{$\begin{array}{l}\text { Coefficient of } \\
\text { water } \\
\text { consumption, } \mathrm{m}^{3} / \mathrm{c}\end{array}$} \\
\hline & Spring & Summer & & & & \\
\hline $\begin{array}{l}\text { Control (without } \\
\text { absorbing agent) }\end{array}$ & 126 & 63 & 457.95 & 5209.5 & 28.0 & 186.0 \\
\hline Control $+\mathrm{N}_{45}$ & 132 & 76 & 457.95 & 5139.5 & 29.9 & 171.9 \\
\hline Aquasorb $20 \mathrm{~kg} / \mathrm{ha}$ & 139 & 73 & 457.95 & 5199.5 & 30.3 & 171.6 \\
\hline Aquasorb $20 \mathrm{~kg} / \mathrm{ha}+\mathrm{N}_{45}$ & 156 & 88 & 457.95 & 5259.5 & 32.2 & 163.3 \\
\hline Aquasorb $40 \mathrm{~kg} / \mathrm{ha}$ & 145 & 81 & 457.95 & 5214.5 & 32.9 & 158.5 \\
\hline Aquasorb $40 \mathrm{~kg} / \mathrm{ha}+\mathrm{N}_{45}$ & 165 & 93 & 457.95 & 5294.5 & 36.5 & 145.1 \\
\hline
\end{tabular}

\section{Conclusion}

The obtained experimental data for the years of research allow making the following conclusions:

- The effective action of the absorbing agent Aquasorb on the increase in the productive moisture in the meter layer of soil of winter wheat was observed especially in the combination with nitrogen top dressing in the dose $\mathrm{N}_{45}$

- The high growth of the winter wheat yield was obtained during the joint application of the absorbing agent and the nitrogen top dressing at the rate of $40 \mathrm{~kg} / \mathrm{ha}$

- For the variants with the application of the absorbing agent and in the complex with the nitrogen top dressing, the more economic use of soil moisture and precipitation was observed in comparison with the control background without application of the absorbing agent. Consequently, the absorbing agent applied into the soil improves significantly the provision of the crop of winter wheat by the available moisture during the vegetation period and also makes it possible to 
efficiently use the moisture for the formation of the heavy yield

\section{Acknowledgement}

The author's sincere gratitude is expressed to the KazRIACP scientific supervisors and colleagues.

\section{Funding Information}

The research was conducted in accordance with an international agreement between KazRIACP (Kazakhstan) and SNF Floerger (France).

\section{Author's Contributions}

Laila Klimovna Tabynbayeva: Provided leadership and coordinated the implementation of research work, analyzed and interpreted the study findings, drew conclusions.

Serik Barmenbekovich Kenenbayev: Conducted research, compiled the literary review, analyzed and interpreted the results.

Meiramgul Shagievna Suleimenova: Involved in all experiments, obtained data analyses and contributed to the scientific writing of the manuscript.

Nurlan Kairbekovich Tinibayev: Involved in all experiments, obtained data analyses and contributed to the scientific writing of the manuscript.

Vasiliy Sergeevich Boiko: Conducted research, compiled the literary review, analyzed and interpreted the results.

\section{Ethics}

This article is original and contains unpublished material. The corresponding author confirms that all of the other authors have read and approved the manuscript and no ethical issues involved.

\section{References}

Abedi-Koupai, J. and F. Sohrab, 2004. Effect evaluation of superabsorbent application on water retention capacity and water potential in three soil textures. J. Sci. Technol. Polym., 17: 163-173.

Al-Darby, A.M., 1996. The hydraulic properties of sandy soil treated with gel forming soil conditioner. Soil Technol., 9: 15-28.

Barihi, R., E. Panahpour and M.H.M. Beni, 2013. Super absorbent polymer (Hydrogel) and its application in agriculture. World Sci. J., 01: 223-228.

Bowman, D.C. and R.Y. Evans, 1991. Calcium inhibition of polyacrylamide gel hydration is partially reversible by potassium. Hort Sci., 26: 1063-1065.
Choudhary, M.I., A.A. Shalaby and A.M. Al Omran, 1995. Water holding capacity and evaporation of calcareous soils as affected by four synthetic polymers. Commun. Soil Sci. Plant Anal., 26: 2205-2215.

Dospekhov, B.A., 1985. Field Test Method. 1st Edn., Agropromizdat, Moscow, pp: 351.

Ekebafe, L.O., D.E. Ogbeifun and F.E. Okieimen, 2011. Polymer applications in agriculture. Biokemistri, 23: 81-89.

Helalia, A.M. and J. Letey, 1989. Effects of different polymers on seedling emergence, aggregate stability and crust hardness. Soil Sci., 148: 199-203.

Hüttermann, A., L.J.B. Orikiriza and H. Agaba, 2009. Application of superabsorbent polymers for improving the ecological chemistry of degraded or polluted lands. Clean Soil, Air, Water, 37: 517-526.

Jhurry, D., 1997. Agricultural Polymers. Mauritius: Food and Agricultural Research Council. 1st Edn., AMAS, Réduit. pp: 113.

Johnson, M.S., 1984. Effect of soluble salts on water absorption by gel-forming soil conditioners. J. Sci. Food Agric., 35: 1063-1066.

Khadem, S.A., M. Galavi, M. Ramrodi, S.R. Mousavi and M.J. Rousta et al., 2010. Effect of animal manure and super absorbent polymer on corn leaf relative water content, cell membrane stability and leaf chlorophyll content under dry condition. Australian J. Crop Sci., 4: 642-647.

Krotov, P.V., 1996. Impact of expanding hydrogels on the optimal moisture provision and nutrition of crops in the crop rotation link Ph.D. Thesis Abstract. Nemchinovka.

Nurbekov, S.I., 2010. Biological criteria of the winter soft wheat selection of the dry steppe agroeco type Doctoral Thesis Abstract. Almalybak.

Orikiriza, L.J.B., H. Agaba, G. Eilu, M. Tweheyo and J.D. Kabasa et al., 2009. Amending soils hydrogels increases the biomass of nine tree species under non-water stress conditions. Clean Soil Air Water, 37: 615-620.

Puoci, F., F. Iemma, U.G. Spizzirri, G. Cirillo and M. Curcio et al., 2008. Polymer in agriculture: A review. Am. J. Agric. Biol. Sci., 3: 299-314.

Sabrah, R.E.A., M.F. Ghoneim, H.M. Abd El-Magid and R.K. Rabie, 1993. Characteristics and productivity of a sandy soil as influenced by soil conditioners in Saudi Arabia. J. Arid Environ., 24: 297-303.

Saifuldeen, A.S., 2014. Effects of water-retaining agent (Sky Gel) on growth, yield and water use efficiency of wheat (Triticumaestivum L.). 